\begin{tabular}{|l|l|l||}
\hline \multicolumn{2}{|c|}{ PublisherInfo } \\
\hline \hline PublisherName & $:$ & BioMed Central \\
\hline \hline PublisherLocation & $:$ & London \\
\hline \hline PublisherImprintName & $:$ & BioMed Central \\
\hline \hline
\end{tabular}

\title{
Novel therapy for cardiogenic shock
}

\begin{tabular}{|l|l|l||}
\hline \multicolumn{2}{|c||}{ ArticleInfo } \\
\hline \hline ArticleID & $:$ & 4196 \\
\hline \hline ArticleDOI & $:$ & $10.1186 /$ ccf-2000-5198 \\
\hline \hline ArticleCitationID & $:$ & 5198 \\
\hline \hline ArticleSequenceNumber & $:$ & 55 \\
\hline \hline ArticleCategory & $:$ & Paper Report \\
\hline \hline ArticleFirstPage & $:$ & 1 \\
\hline \hline ArticleLastPage & $:$ & 3 \\
\hline \hline & & RegistrationDate : 2000-5-22 \\
\hline ArticleHistory & $:$ & OnlineDate \\
\hline \hline ArticleCopyright & $:$ & Current Science Ltd2000-5-22 \\
\hline \hline ArticleGrants & $:$ & \\
\hline \hline ArticleContext & $:$ & 1305422 \\
\hline \hline
\end{tabular}




\section{Keywords}

\section{Comments}

Cardiogenic shock complicates acute myocardial infarction (AMI) and carries a high mortality rate despite therapy. Conventional therapy includes coronary revascularisation, afterload reduction, ionotropes and mechanical adjuncts including ventilation and intra-aortic balloon pump (IABP). Nitric oxide (NO) is involved in vasodilation. In this uncontrolled trial, $\mathrm{N}^{\mathrm{G}}$-monomethyl-L-arginine (LNMMA), a nonspecific nitric oxide synthetase inhibitor, was administered to promote vasoconstriction in order to augment blood pressure (BP). There were no untoward effects or deaths directly attributable to the drug, and 10 of the 11 patients showed improvement. As the authors themselves point out, this is a preliminary report of a drug showing promise which needs to be studied further.

\section{Introduction}

A study to assess the safety and efficacy of L-NMMA in the treatment of cardiogenic shock.

\section{Methods}

. Eleven consecutive patients with extensive AMI complicated by cardiogenic shock

. All mechanically ventilated/IABP

. Coronary angiography + primary percutaneous transluminal coronary angioplasty when feasible

. All commenced on dopamine/dobutamine/frusemide infusions 
. Cardiogenic shock defined as persistent unaugmented systolic BP $<100 \mathrm{~mm} \mathrm{Hg}$, accompanied by pulmonary congestion (on chest X-ray), cardiac index $(\mathrm{CI})<2.5 \mathrm{~L} / \mathrm{min} / \mathrm{m}^{2}$ and wedge pressure $>15 \mathrm{~mm}$ Hg despite therapy.

. Patients with tachyarrhythmia/bradyarrhythmia, mechanical complication, fever $>38^{\circ} \mathrm{C}$, creatinine $>$ $200 ? \mathrm{~mol} / \mathrm{mL}$

. L-NMMA was administered intravenously, initially as bolus of $1 \mathrm{mg} / \mathrm{kg}$ then as an infusion of $1 \mathrm{mg} /$ $\mathrm{kg} / \mathrm{h}$ for $5 \mathrm{~h}$.

\section{Results}

Within 10 min mean arterial pressure (MAP) increased from 76 ? 9 to 109 ? $22 \mathrm{~mm} \mathrm{Hg}$. CI initially fell from 2.0 ? 0.5 to $1.7 ? 0.4 \mathrm{~L} / \mathrm{min} / \mathrm{m}^{2}$; however, after discontinuation it rose to $1.85 ? 0.4 \mathrm{~L} / \mathrm{min} / \mathrm{m}^{2}$. Urine output (UO) increased by $148 \%$. The positive changes in MAP and UO persisted after $24 \mathrm{~h}$. Ten of the eleven patients were weaned off ventilation and IABP; eight were discharged from the coronary care unit and seven were alive at the 1 month follow-up.

\section{Additional information}

Trials of L-NMMA in septic shock have been disappointing, and interestingly there was an alarming amount of electrocardiographic evidence of myocardial ischaemia. (Mayr et al Crit Care Med 1996, 24:1930-1930 and Grover et al, Crit Care Med 1999, 27:913-922). The 1999 Nobel prize in medicine was awarded to Drs Robert\%20Furchgott, Louis\%20Ignarro, and Ferid\%20Murad for their discoveries that vascular endothelial cells make NO and that NO stimulates cyclic-guanosine monophosphate synthesis in the smooth muscle cells, causing relaxation. This is controlled by endothelial NO synthetase.

\section{References}

1. Cotter G, Kaluski E, Blatt A, Milovanov O, Moshkovitz Y, Zaidenstein R, Salah A, Alon D, Michovitz Y, Metzger M, Vered Z, Golik A: L-NMMA (a nitric oxide synthetase inhibitor) is effective in the treatment of cardiogenic shock. Circulation. 2000, 101: 1358-1361.

This PDF file was created after publication. 